Article

\title{
Leaching of Metals from Waste Silver Oxide-Zinc Button Cell Batteries by Aspergillus niger
}

\author{
Umesh Jadhav $^{1}$, Chun-Hui Su ${ }^{2}$, Mital Chakankar ${ }^{2}$ (D) and Hong Hocheng ${ }^{2, *(D)}$ \\ 1 Department of Microbiology, Savitribai Phule Pune University, Pune 411007, India; \\ umeshjadhav02@gmail.com \\ 2 Department of Power Mechanical Engineering, National Tsing Hua University, No. 101, Sec. 2, \\ Kuang Fu Rd., Hsinchu 30013, Taiwan; ichichirosu@gmail.com (C.-H.S.); jadhavmital@gmail.com (M.C.) \\ * Correspondence: hochengh@gmail.com; Tel.: +886-3-516-2097
}

Received: 23 August 2018; Accepted: 15 October 2018; Published: 17 October 2018

\begin{abstract}
Leaching of metals from waste button cell batteries was explored in this study. Aspergillus niger spent medium was used for metal leaching to avoid toxicity of metals toward microbial cells. Process parameters including time, temperature, shaking speed, and volume of the spent medium were optimized. We obtained $100 \%$ leaching of zinc and silver in six hours at $60^{\circ} \mathrm{C}$ and $100 \mathrm{rpm}$ using $15 \mathrm{~mL}$ spent medium. The use of spent medium supported the indirect leaching process. The organic acid produced by fungi acts as a lixiviant, aiding the metal leaching in this process.
\end{abstract}

Keywords: button cell batteries; silver; Zinc; Aspergillus niger; culture supernatant; two-step bioleaching

\section{Introduction}

The trend of miniaturization of various products and devices has led to the wide use of button cell batteries. Considering their operating longevity, small size, as well as high capacity per unit mass, they are used to power many portable electronic devices like wristwatches, calculators, toys, hearing aids, and medical devices [1]. These disposable batteries turn into waste after their life is over and long storage results in inactivation of these batteries [2].

Heavy metals present in such batteries entail severe environmental and health risks if improperly disposed; hence, recycling these batteries is crucial. Although these batteries are hazardous when disposed of in nature, they are rich repositories of valuable metals. Thus, recycling of waste batteries is advantageous to protect the environment and to recover valuable metals. Conventional techniques, such as pyro- and hydrometallurgy, are used to extract metals from these wastes [1,2]. Although these methods are fast and efficient, they require high energy and emit toxic gases and chemicals, so these processes are expensive and cause secondary pollution [3]. There is a need to develop an eco-friendly and sustainable process to recycle waste button cell batteries. Bioleaching is a process that uses microorganisms to recover metals. This process operates under mild conditions. It reduces the energy and material consumption, which makes the process eco-friendly [4-6]. Aspergillus niger was selected to leach metals from button cell batteries, since fungi are more advantageous compared to bacteria in the bioleaching process. They can grow at high $\mathrm{pH}$, produce lixiviants, like organic acids that chelate metal ions, and stimulate the rate of metal leaching [7]. In this study, the spent medium bioleaching process was used. For industrial applications, bioleaching by the spent medium is desirable to achieve high leaching efficiency [8]. Generally, spent medium bioleaching is preferable owing to the independent lixiviant generation and separate chemical process that allows individual process optimization of each step, resulting in maximum productivity. So, the spent medium process was utilized in the current investigation to recover silver from spent button cell batteries. 


\section{Materials and Methods}

\subsection{Materials}

Chemicals were procured from Sigma Aldrich (St. Louis, MO, USA). The solutions were prepared using deionized water. The waste button cell batteries were obtained from a local market. The powder, containing silver (Ag), zinc ( $\mathrm{Zn})$, and mercury $(\mathrm{Hg})$, was collected by manually dismantling waste button cell batteries. The powder was dried at $60^{\circ} \mathrm{C}$ before experiments.

\subsection{Determination of Metal Content of Waste Button Cell Battery Powder}

The aqua regia method was used for the digestion of waste button cell battery powder. The digested solution was filtered using a $0.45 \mu \mathrm{m}$ membrane filter and diluted before determining its metal content using an inductively-coupled plasma-optical emission spectrometry (ICP-OES, Perkin Elmer, Waltham, MA, USA). Table 1 shows the metal content of the waste button cell battery powder.

Table 1. The metal content of button cell battery.

\begin{tabular}{cc}
\hline Metal & Metal Content $(\mathbf{m g} / \mathbf{g})$ \\
\hline $\mathrm{Zn}$ & $290 \pm 0.82$ \\
$\mathrm{Ag}$ & $35.86 \pm 0.31$ \\
$\mathrm{Hg}$ & $6.30 \pm 0.06$ \\
$\mathrm{Fe}$ & $0.02 \pm 0.001$ \\
\hline
\end{tabular}

\subsection{Microorganism Used and Spent Medium Collection}

A. niger, obtained from the Food Industry Research and Development Institute (FIRDI), Hsinchu, Taiwan, was grown on sucrose medium. The media included sucrose (100 g), $\mathrm{NaNO}_{3}(1.5 \mathrm{~g}), \mathrm{KH}_{2} \mathrm{PO}_{4}$ $(0.5 \mathrm{~g}), \mathrm{MgSO}_{4} \cdot 7 \mathrm{H}_{2} \mathrm{O}(0.025 \mathrm{~g}), \mathrm{KCl}(0.025 \mathrm{~g})$, and yeast extract (1.6 g) per liter of glass-distilled water [9]. A. niger was grown at $30{ }^{\circ} \mathrm{C}$ and $120 \mathrm{rpm}$ for 10 days. The fungus produced only citric acid using sucrose as reported earlier [10]. Considering the earlier results, the spent medium in this study was collected after incubating $A$. niger at $25^{\circ} \mathrm{C}$ and $120 \mathrm{rpm}$ for 10 days. The spent medium had a citric acid concentration of $20 \mathrm{~g} / \mathrm{L}$ and $\mathrm{pH} 1.97$ [10]. The spent medium was filtered through a $0.22 \mu \mathrm{m}$ filter before the experiments.

\subsection{Various Physicochemical Parameters}

To study the effect of time, $0.10 \mathrm{~g}$ waste battery powder was added to $100 \mathrm{~mL}$ spent medium in a $250 \mathrm{~mL}$ flask and incubated $30{ }^{\circ} \mathrm{C}$ and $150 \mathrm{rpm}$. The samples were collected in $2 \mathrm{~h}$ increments up to $8 \mathrm{~h}$ and were sent for metal analysis.

The waste battery powder $(0.10 \mathrm{~g})$ was added to $100 \mathrm{~mL}$ spent medium in a $250 \mathrm{~mL}$ flask. The temperature was varied from 30 to $60{ }^{\circ} \mathrm{C}$ to examine the effect of temperature on metal leaching.

The effect of shaking speed on leaching of metals was studied by adding spent battery powder $(0.10 \mathrm{~g})$ in $100 \mathrm{~mL}$ spent medium in $250 \mathrm{~mL}$ flasks at $60{ }^{\circ} \mathrm{C}$ and varying the shaking speed from 0 to $150 \mathrm{rpm}$ for the leaching experiment. Samples were collected from the flasks after leaching the solution for $8 \mathrm{~h}$.

The varying volumes of spent medium from 5 to $20 \mathrm{~mL}$ in a $50 \mathrm{~mL}$ flask were employed for the study. We added $0.10 \mathrm{~g}$ waste battery powder and flasks were placed at $60{ }^{\circ} \mathrm{C}$ and $150 \mathrm{rpm}$. Samples were collected from the flasks after leaching the solution for $8 \mathrm{~h}$.

\subsection{Analytical Methods}

The metal concentrations in the leaching solutions were analyzed with a Kontron S-35, inductively coupled plasma optical emission spectrometry (ICP-OES). The experiments were run in triplicates. 


\section{Results and Discussion}

\subsection{Leaching of Metals from Button Cell Battery Powder}

The increasing amount of battery waste and the presence of hazardous and precious metals has raised environmental and economic concerns. We report the use of microorganisms as an eco-friendly and sustainable approach for the metal reclamation from the battery waste. The process described here involves the use of microbial culture supernatant, which is the most preferable method from an industrial application viewpoint. The bioleaching potential of $A$. niger is well known and is credited with organic acids production, mainly citric acid, which acts as lixiviants for metal recovery.

\subsection{Various Physicochemical Parameters}

The $A$. niger spent medium was used to explore the leaching of metals from button cell batteries. Figure 1 shows the pattern of metal leaching at different time intervals. In the first four hours, only $27 \%$ of Ag was leached, while $64 \%$ of $\mathrm{Zn}$ was leached. The elevation in leaching of metals was observed with an increase in incubation time up to six hours. No significant effect was noted on leaching of metals by further incubating for eight hours. Around $80 \% \mathrm{Zn}$ and $41 \% \mathrm{Ag}$ were leached after six hours of incubation. These results indicate that citric acid effectively solubilized Zn from waste button cell batteries. Citric acid was reported to play a key role in the recovery of Zn from Zn-Mn batteries [3]. The leaching of $\mathrm{Hg}$ was not satisfactory. Only $2 \%$ leaching was achieved using $A$. niger spent medium for six hours (Figure 1).

Similar results were observed by Sathaiyan et al. [2] and Aktas [1]. They required 50 and $60 \mathrm{~min}$ for dissolution of $\mathrm{Ag}$, respectively. In their studies, they used a high concentration of nitric acid. The present results are favorable as compared to those of Sathaiyan et al. [2] and Aktas [1] since A. niger spent medium contain citric acid has less impact on the environment.

The temperature influenced the leaching results as depicted in Figure 2. Studies were carried out at varying temperatures ranging from 20 to $60^{\circ} \mathrm{C}$. At lower temperatures $\left(30^{\circ} \mathrm{C}\right)$ only around 80,41 , and $2 \%$ leaching was observed for $\mathrm{Zn}, \mathrm{Ag}$, and $\mathrm{Hg}$, respectively. Increases in incubation temperature favored the metal leaching. The $100 \%$ leaching of $\mathrm{Zn}$ and Ag were achieved at $60{ }^{\circ} \mathrm{C}$. Around $11 \%$ $\mathrm{Hg}$ was leached at $60{ }^{\circ} \mathrm{C}$. Thus, $60^{\circ} \mathrm{C}$ was found to be the optimum temperature for silver extraction and was therefore employed in all subsequent experiments. Aktas [1] remarked on the influence of temperature in the silver dissolution from spent button cells. Yoo et al. [11] obtained the similar results indicating elevated effective dissolution of $\mathrm{Ag}$ and $\mathrm{Cu}$ from solders at higher temperatures.

Leaching of metals from waste battery powder using $A$. niger spent medium was evaluated by varying shaking speed from 50 to $200 \mathrm{rpm}$. Higher leaching of metals was detected as the shaking speed increased, resulting in 100\% extraction of $\mathrm{Zn}$ and Ag at $100 \mathrm{rpm}$ (Figure 3). Further increases in shaking speed to $150 \mathrm{rpm}$ decreased the metal leaching efficiency. Yoo et al. [11] proposed that higher shaking speeds keep the mineral particles suspended in the solution. Therefore, a higher shaking speed is essential for effective particle suspension in the solution [12]. Aktas [1] reported a similar observation suggesting the impact of diffusion-controlled kinetic factors on the dissolution of Ag. 


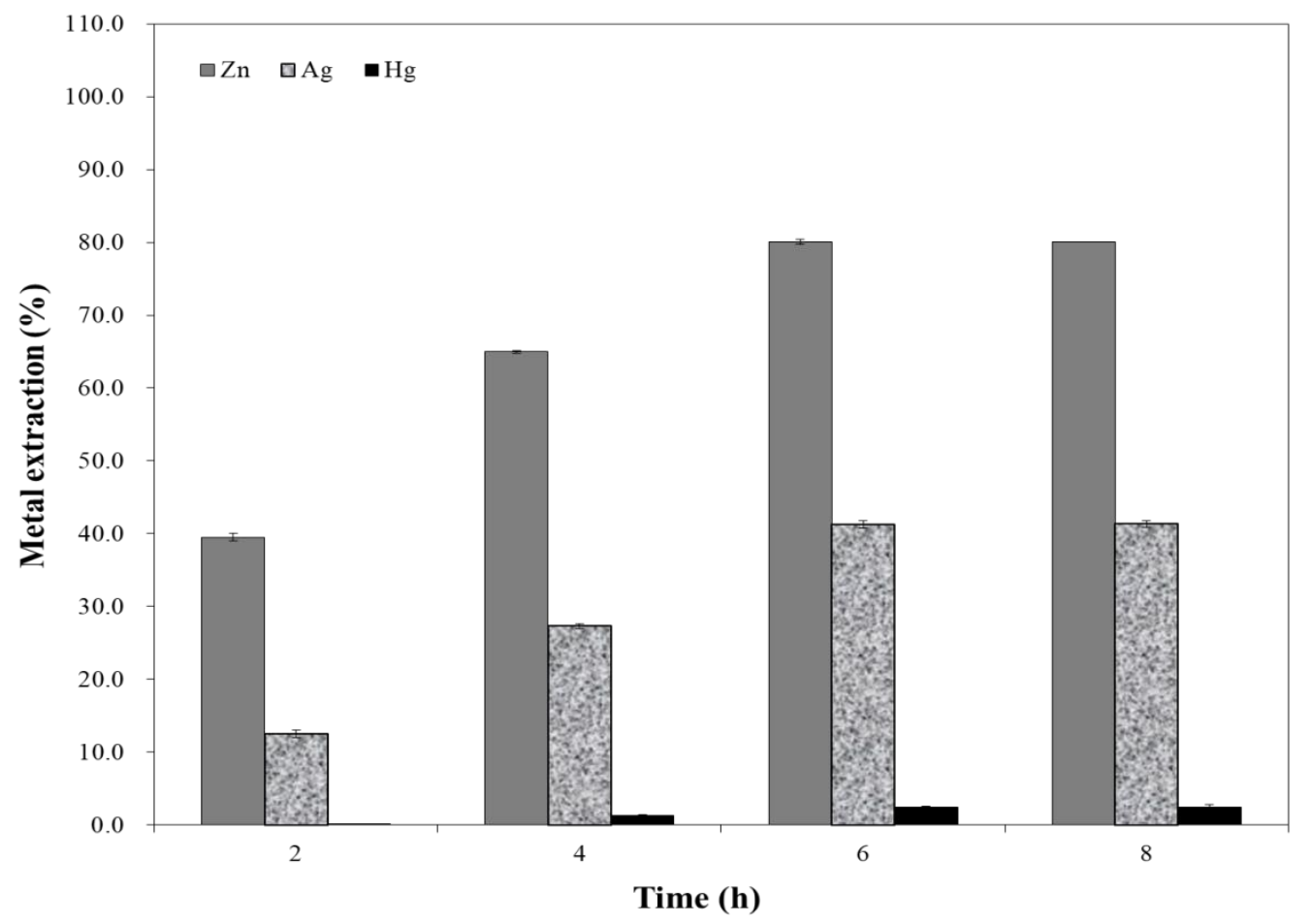

Figure 1. Evaluation of time period for leaching of metals using $100 \mathrm{~mL}$ A. niger spent medium at $30^{\circ} \mathrm{C}$ and $150 \mathrm{rpm}$.

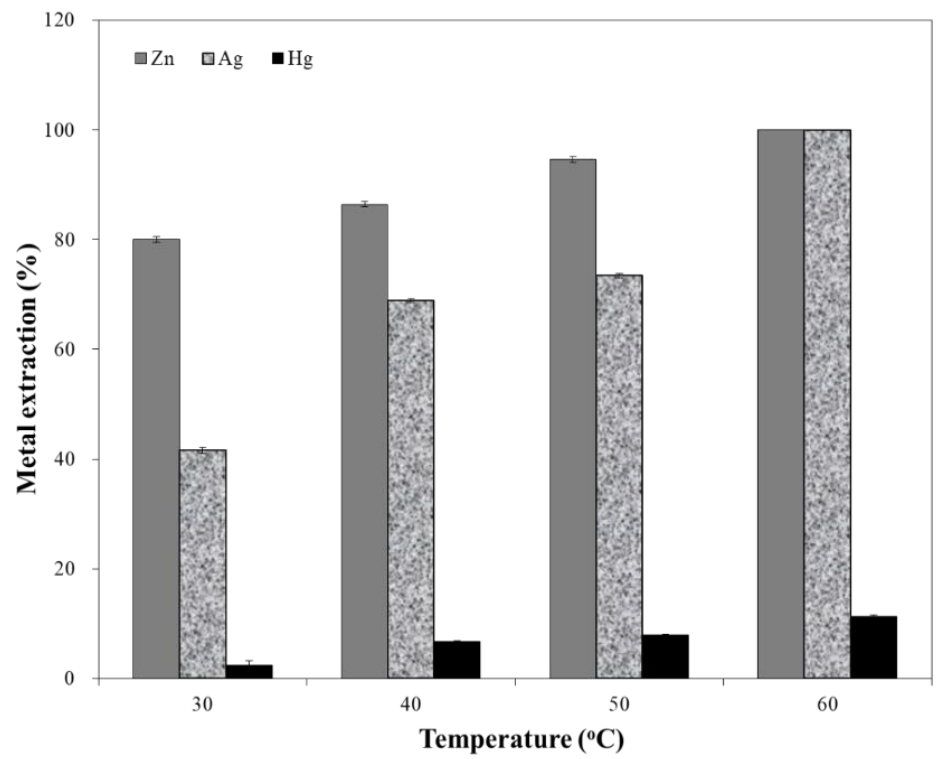

Figure 2. Effect of temperature on metal leaching using $100 \mathrm{~mL}$ A. niger spent medium after six hours of incubation and $150 \mathrm{rpm}$. 


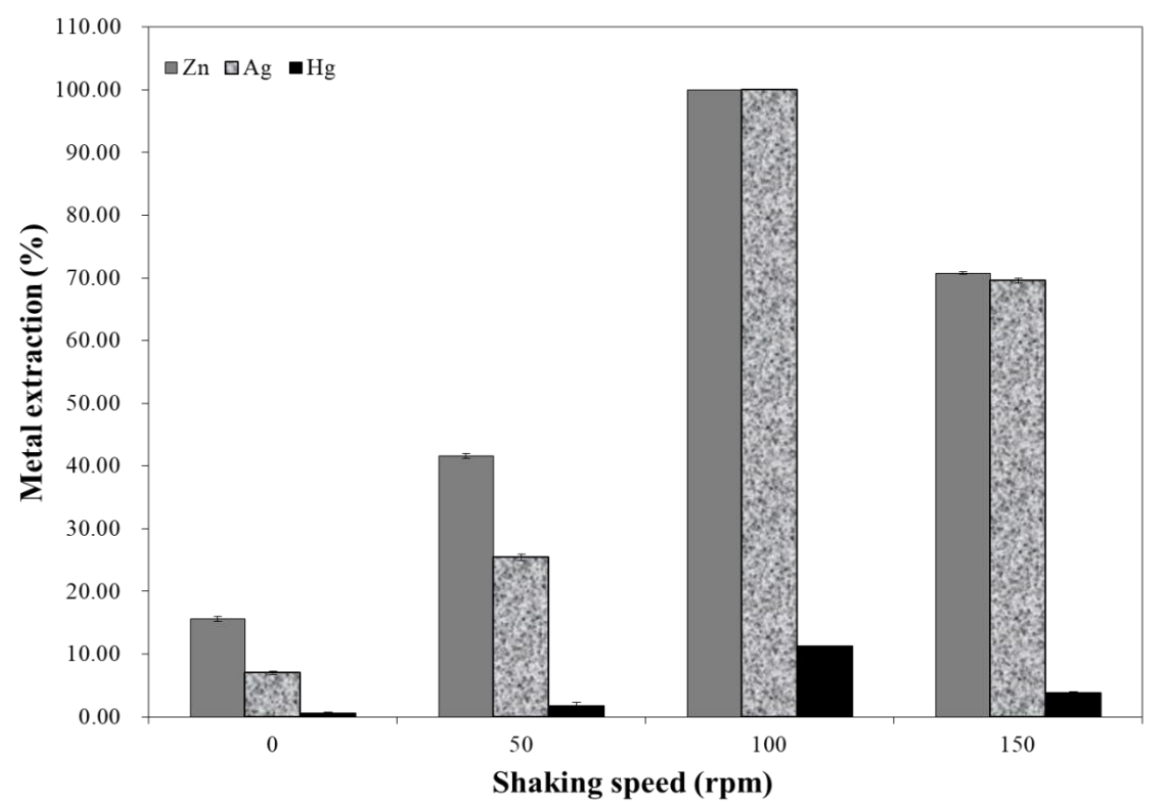

Figure 3. Effect of shaking speed on metal leaching using $100 \mathrm{~mL}$ A. niger spent medium after six hours of incubation at $60^{\circ} \mathrm{C}$.

The volume of spent medium also influenced the leaching of metals, resulting in higher leaching efficiency with an increase in volume up to $15 \mathrm{~mL}$ (Figure 4). Further increase in volume had no positive effect on metal leaching. The substantial volume of the spent medium assisted the transport of the ionic product from spent powder. However, this effect was saturated above $15 \mathrm{~mL}$ [13]. These outcomes suggest that the $A$. niger spent medium is an effective leaching agent for recovery of $\mathrm{Zn}$ and Ag from spent button cell batteries.

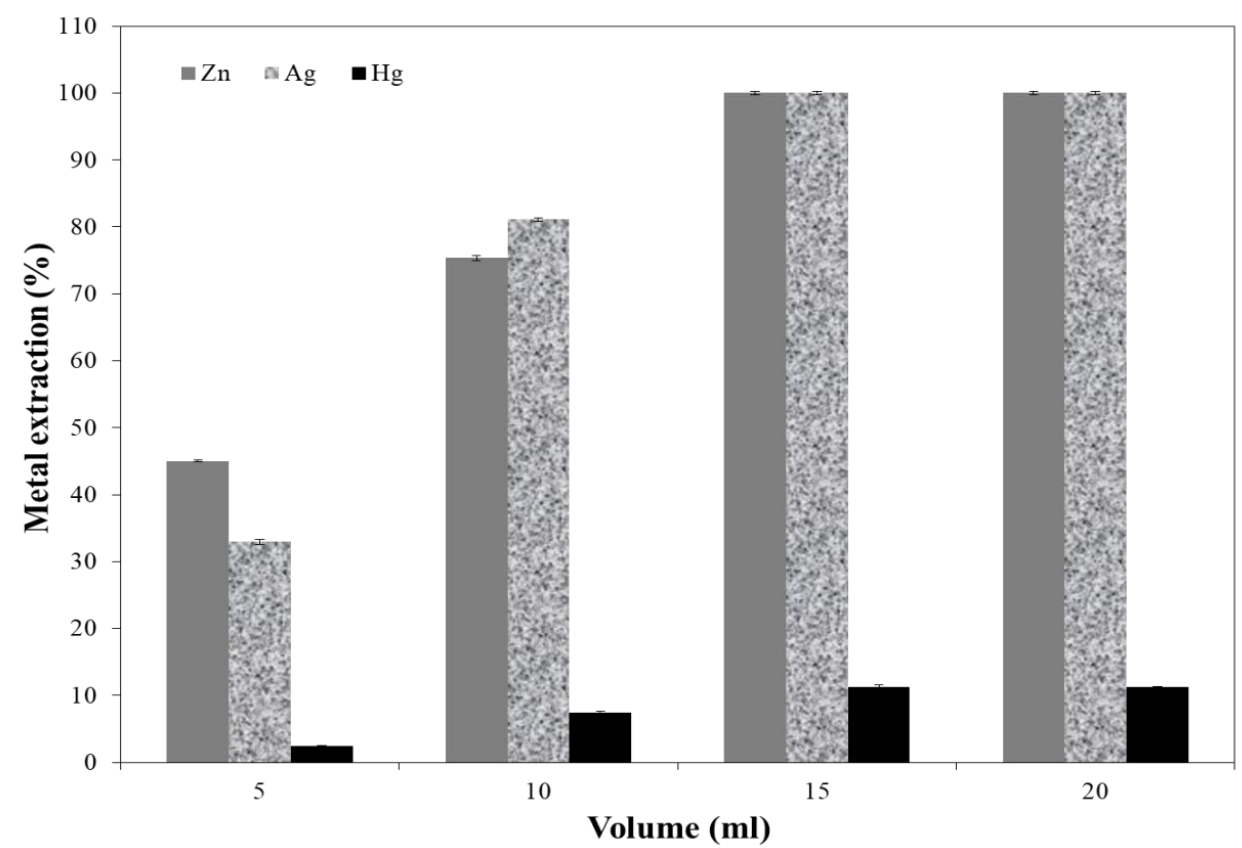

Figure 4. Effect of $A$. niger spent medium volume on leaching of metals after six hours of incubation at $60^{\circ} \mathrm{C}$ and $100 \mathrm{rpm}$.

Table 2 compares the current and earlier studies by our group. In a previous study, the spent culture medium of Acidithiobacillus ferrooxidans was used to leach Ag from button cell batteries [6]. As silver is toxic to microbial cells, in the previous study, Acidithiobacillus ferrooxidans was grown in 
growth medium for the production of $\mathrm{Fe}^{3+}$. Then, the spent culture medium containing $\mathrm{Fe}^{3+}$ was used for the leaching process. Aktas [1] suggested that during power generation using button cell batteries, silver oxide is reduced to metallic silver and zinc metal is converted to zinc oxide. The overall reaction can be given as follows $[1,14]$ :

$$
\mathrm{Ag}_{2} \mathrm{O}_{(\mathrm{s})}+\mathrm{Zn}^{0} \rightarrow 2 \mathrm{Ag}^{0}+\mathrm{ZnO}_{(\mathrm{s})}
$$

Table 2. A comparisons between current and earlier studies for recovery of metals from spent silver oxide-zinc button cell batteries.

\begin{tabular}{ccccc}
\hline \multirow{2}{*}{ Reference } & Micro-Organism Used & \multicolumn{2}{c}{ Metal Recovery (\%) } & \multirow{2}{*}{ Time Required (h) } \\
\cline { 3 - 4 } & & Ag & Zn & \\
\hline Jadhav and Hocheng [6] & Acidithiobacillus ferrooxidans & 100 & NA & 1 \\
\hline Jadhav et al. (Present study) & Aspergillus niger & 100 & 100 & 6 \\
\hline
\end{tabular}

The bioleaching process using Acidithiobacillus ferrooxidans is based on oxidizing potential of $\mathrm{Fe}^{3+}$. The zinc metal cannot be leached using Acidithiobacillus ferrooxidans, since the zinc present in button cell batteries is already in the oxidized form. The $\mathrm{Fe}^{3+}$ produced by Acidithiobacillus ferrooxidans can only solubilise the reduced metallic silver from button cell batteries. Although silver recovery required much less time compared to this study, the drawback of using At. ferrooxidans is that it was not able to leach $\mathrm{Zn}$. To overcome this problem $A$. niger, a bioleaching system based on organic acid production, was used in this study.

\section{Conclusions}

In the present study, a spent medium bioleaching process was employed to leach Zn and Ag from spent button cell batteries. Findings indicated 100\% leaching of $\mathrm{Zn}$ and Ag was achieved using $15 \mathrm{~mL}$ A. niger culture supernatant with a six hour incubation period at $60{ }^{\circ} \mathrm{C}$ and $100 \mathrm{rpm}$. These results suggest that an environmentally-friendly process can be developed for leaching metals from button cell batteries using $A$. niger culture supernatant.

Author Contributions: Conceptualization, U.J.; Formal analysis, U.J. and M.C.; Investigation, U.J. and C.-H.S.; Methodology, U.J. and C.-H.S.; Writing—original draft, U.J. and M.C.; Writing-review \& editing, M.C. and H.H.

Funding: This research was funded by the National Science Council of Taiwan under contract 100-2221-E-007-015-MY3.

Conflicts of Interest: The authors declare no conflict of interest.

\section{References}

1. Aktas, S. Silver recovery from spent silver oxide button cells. Hydrometallurgy 2010, 104, 106-111. [CrossRef]

2. Sathaiyan, N.; Nandakumar, V.; Ramachandran, P. Hydrometallurgical recovery of silver from waste silver oxide button cells. J. Power Source 2006, 161, 1463-1468. [CrossRef]

3. Kim, M.; Seo, J.; Choi, Y.; Kim, G. Bioleaching of spent Zn-Mn or Ni-Cd batteries by Aspergillus species. Waste Manag. 2016, 51, 168-173. [CrossRef] [PubMed]

4. Miller, J.; Li, J.; Davidtz, J.; Vos, F. A review of pyrrhotite flotation chemistry in the processing of PGM ores. Minerals Eng. 2005, 18, 855-865. [CrossRef]

5. Cui, J.; Zhang, L. Metallurgical recovery of metals from electronic waste: A review. J. Hazard. Mater. 2008, 158, 228-256. [CrossRef] [PubMed]

6. Jadhav, U.; Hocheng, H. Extraction of silver from spent silver oxide zinc button cells by using Acidithiobacillus ferrooxidans culture supernatant. J. Clean. Prod. 2013, 44, 39-44. [CrossRef]

7. Burgstaller, W.; Schinner, F. Leaching of metals with fungi. J. Biotechnol. 1993, 27, 91-116. [CrossRef]

8. Hocheng, H.; Chang, J.; Jadhav, U. Micromachining of various metals by using Acidithiobacillus ferrooxidans 13820 culture supernatant experiments. J. Clean. Prod. 2012, 20, 180-185. [CrossRef] 
9. Xu, T.; Ting, Y. Fungal bioleaching of incineration fly ash: Metal extraction and modeling growth kinetics. Enzyme Microb. Technol. 2009, 44, 323-328. [CrossRef]

10. Jadhav, U.; Hocheng, H. Use of Aspergillus niger 34770 culture supernatant for tin metal removal. Corros. Sci. 2014, 82, 248-254. [CrossRef]

11. Yoo, K.; Lee, J.; Lee, K.; Kim, B.; Kim, M.; Kim, S.; Pandey, B.D. Recovery of Sn, Ag and Cu from waste $\mathrm{Pb}$-free solder using nitric acid leaching. Mater. Transact. 2012, 53, 2175-2180. [CrossRef]

12. Espiari, S.; Rashchi, F.; Sadrnezhaad, S. Hydrometallurgical treatment of tailings with high zinc content. Hydrometallurgy 2006, 82, 54-62. [CrossRef]

13. Jadhav, U.; Hocheng, H.; Weng, W. Innovative use of biologically produced ferric sulfate for machining of copper metal and study of specific metal removal rate and surface roughness during the process. J. Mater. Proc. Technol. 2013, 213, 1509-1515. [CrossRef]

14. Compton, T. Battery Reference Book, 3rd ed.; Newnes: Reed, UK, 2000.

(C) 2018 by the authors. Licensee MDPI, Basel, Switzerland. This article is an open access article distributed under the terms and conditions of the Creative Commons Attribution (CC BY) license (http://creativecommons.org/licenses/by/4.0/). 